\title{
Effects of Alloying Elements and Condensed Film of the Inner Wall of Vacuum Fusion Apparatus on the Carbon Monoxide and Nitrogen Extraction*
}

\author{
By Takeji Koizumi**, Fujio Tsugane** and Masataka Kamakura**
}

\begin{abstract}
Synopsis
The authors made some experiments with respect to the nitrogen and carbon monoxide extractions by the vacuum fusion method for the analysis of gases in steels. As for the nitrogen gas, the variation of results in the run of analysis and the influence of alloying elements were investigated to compare with the results obtained by chemical analysis. On the other hand, the lowering tendency of oxygen values in the pure iron by the addition of $\mathrm{Al}$ or $\mathrm{Mn}$, relating with the effect of $\mathrm{Mo-hood,} \mathrm{was} \mathrm{studied.} \mathrm{Temperature}$ measurements at the inner wall surface of the furnace tube and the analyses of the condensed metallic film on the surface and of the residual metals in the graphite crucible were also performed. (1) Ascertained that some elements like $\mathrm{Cr}, \mathrm{V}, \mathrm{Mo}$ and $\mathrm{Al}, \mathrm{Mn}$ are harmful for the extraction of nitrogen and carbon monoxide, respectively. (2) Studied the cause and mechanism of the insufficient nitrogen extraction where its values are lower than those in the chemical analysis. (3) Discussed the carbon monoxide adsorption mechanism of the film of the inner wall mainly composed of $\mathrm{Fe}, \mathrm{Mn}$ and $\mathrm{Al}$. Then it was found that the Mo-hood was considerably effective in preventing such a phenomenon.
\end{abstract}

\section{Introduction}

The vacuum fusion method for the gas analysis of steels has been used in conjunction with a number of improvements introduced since 1920. Now it is regarded as a most common procedure and the data obtained through this method are considered as the basis in the other analyses.

In spite of this reliability, there are some problems to be solved, which cause errors in values. In this paper the authors concentrated on one of these problems and studied the influence of alloying elements on the extraction of gases.

As for the nitrogen, investigation was made on the relations between the extraction tendency and the blank values of the molten sample, which contained the elements of $\mathrm{Cr}, \mathrm{V}$ and Mo which increase the solubility of nitrogen in liquid steels. On the carbon monoxide gas extraction it is well-known, as was pointed out by G. Thanheiser, N. Yoneda and S. Sawa that if Al or
$\mathrm{Mn}$ is contained in a sample, it lowers the oxygen value. Though it is said that this is caused by the carbon monoxide adsorption on the inner wall of the furnace tube, the exact quantitative relation between $\mathrm{Al}$ or $\mathrm{Mn}$ content and oxygen values have not hitherto been made clear. Therefore, in order to solve this relationship the authors studied the influence of $\mathrm{Al}$ or $\mathrm{Mn}$ addition to the pure iron and steel of various chemical compositions. Then the Mo-hood covering the quartz tube was revealed as being considerably effective for the prevention of the film condensation. In addition, after the temperature measurements at the inner surface of the furnace tube and the gas analysis were made, the analyses of the metallic film condensed on the inner surface and the residual metals in the graphite crucible were performed and at the same time the behavior of $\mathrm{Al}$ or Mn during the extraction of gases and the mechanism of carbon monoxide adsorption on that film were investigated.

\section{Apparatus and Procedure}

Both the constant volume pressure measuring type (Rigo-sha model SHO-II) and the constant pressure Orsat type (similar to that recommended by the Japan Society for the Promotion of Science for $\mathrm{H}$ analysis) apparatuses, shown in Figs. 1 and 2, were used.

In Table 1 , the capacity and analytical conditions are compared for the two apparatus. It is noticed that the capacity of the extraction pump of the former apparatus is twice as great as that of the latter while its extraction time is less than one third of the latter.

In the analyses of the condensed film covered on the furnace tube and the residual metals in the graphite crucible, the tube and the crucible were removed from the apparatus after gas analyses, dissolved into acid solution and subjected to the chemical analysis.

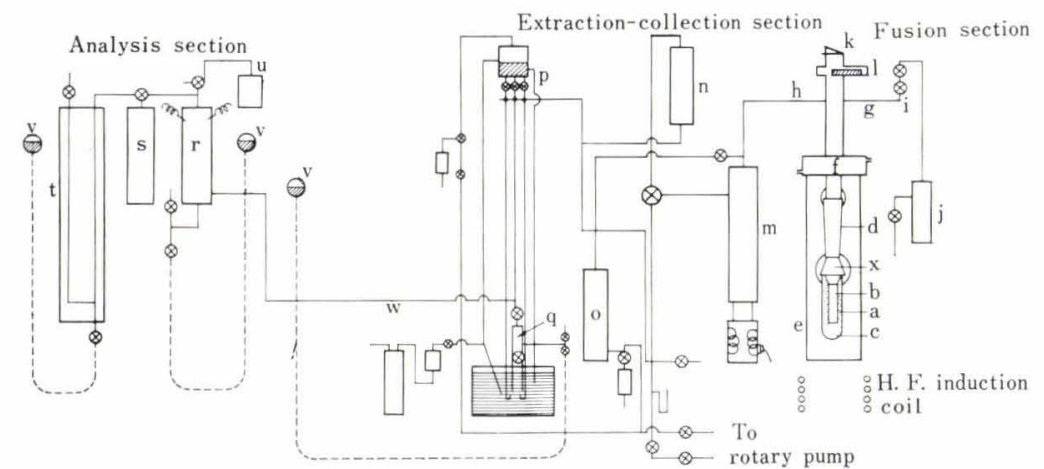

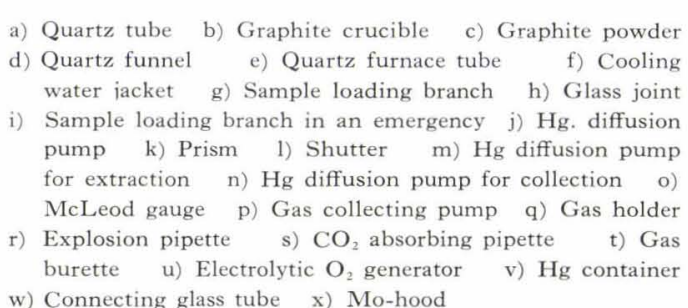

w) Connecting glass tube x) Mo-hood

Fig. 1.

Vacuum fusion apparatus for determining gases in metals. (Constant pressure Orsat type)

* This article is in reference to the lecture delivered before the 64th Grand Lecture Meeting of The Iron \& Steel Institute of Japan in October 1962. Japanese texts were received on August 15 and November 4, 1962 and separately printed in Tetsu-to-Hagané (Journal, Iron \& Steel Institute, Japan), 50 (1964), 5, 787-793 ; 6, 925-933.

** Tokushu Seiko Co., Ltd. 


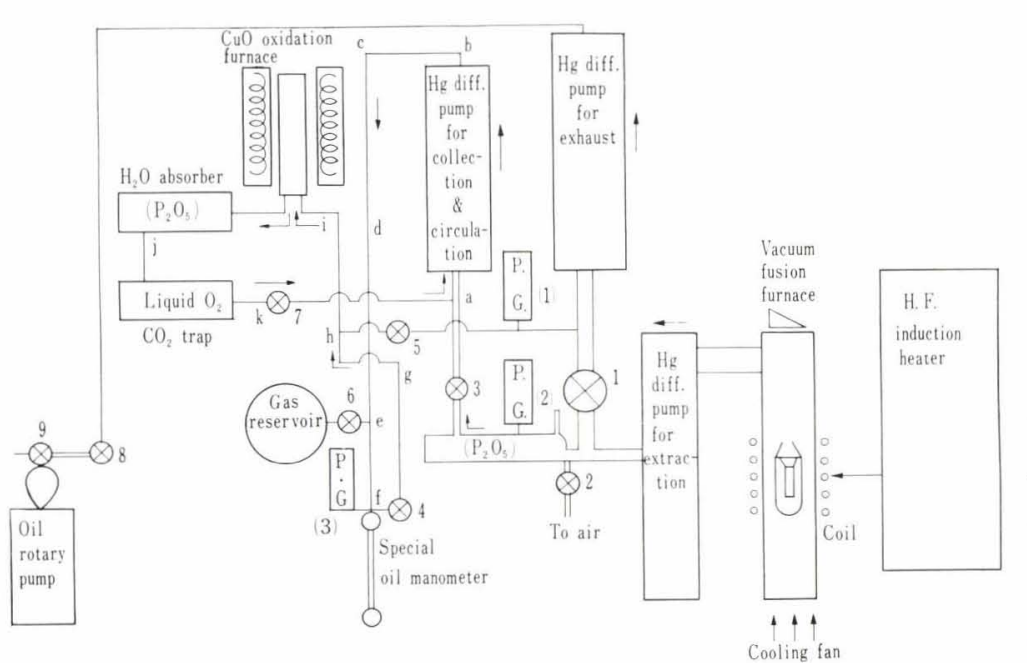

1 9: cocks

(1) (2) (3): pirani gauge

$\mathrm{a} \sim \mathrm{k}$ : circulation path for analysis

Fig. 2.

Block diagram of the vacuum fusion apparatus for determining gases in metals. (Constant volume pressure measuring type)

Table 1. Comparison of the analytical conditions of the apparatus used

\begin{tabular}{|c|c|c|c|c|c|c|c|}
\hline \multirow{2}{*}{ Apparatus } & \multicolumn{2}{|c|}{ Graphite crucible } & \multirow{2}{*}{$\begin{array}{l}\text { Diameter of } \\
\text { furnace tube } \\
(\mathrm{mm})\end{array}$} & \multirow{2}{*}{$\begin{array}{l}\text { Extraction } \\
\text { capacity of } \\
\text { Hg diff. pump } \\
(l / \mathrm{sec})\end{array}$} & \multirow{2}{*}{$\begin{array}{l}\text { Sample } \\
\text { weight } \\
\text { (g) }\end{array}$} & \multirow{2}{*}{$\begin{array}{l}\text { Extraction } \\
\text { temp. } \\
\left({ }^{\circ} \mathrm{C}\right)\end{array}$} & \multirow{2}{*}{$\begin{array}{c}\text { Extraction } \\
\text { time } \\
\text { (min) }\end{array}$} \\
\hline & $\begin{array}{c}\begin{array}{c}\text { Inner } \\
\text { diameter } \\
(\mathrm{mm} \phi \dot{)})\end{array} \\
\end{array}$ & $\begin{array}{c}\text { Depth } \\
(\mathrm{mm})\end{array}$ & & & & & \\
\hline $\begin{array}{l}\text { Const. vol. press. } \\
\text { measuring type }\end{array}$ & 18 & 65 & (outer) & $\max .60$ & 2.0 & 1,850 & $5 \sim 8$ \\
\hline $\begin{array}{l}\text { Const. press. } \\
\text { Orsat type }\end{array}$ & 11 & 55 & (inner) & $25 \sim 30$ & $3.5 \sim 4.0$ & $\begin{array}{l}\text { (Drop in at } \\
1,550) \\
1,850\end{array}$ & 30 \\
\hline
\end{tabular}

\section{Experimental Results}

\section{Extraction of Nitrogen}

By the vacuum fusion method the extraction of nitrogen in steels tends to be delayed than that of carbon monoxide as seen in some references, ${ }^{4)}{ }^{6)}$ where-

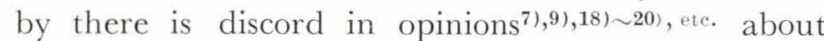
reliability of the nitrogen determination by this method. The authors studied this point and made experiments with the ordinary samples on the effect of the $\mathrm{Cr}, \mathrm{V}$ and Mo which increase the nitrogen solubility.

(1) To observe the process of nitrogen extraction, the total extraction time of $30 \mathrm{~min}$. was divided into the first half of $20 \mathrm{~min}$., and the latter half of $10 \mathrm{~min}$., and the composition of the gas extracted at each period was obtained. The mean values in the 10 times analyses in the latter $10 \mathrm{~min}$. of the reaction for the ordinary high $\mathrm{Cr}$ steel $(\mathrm{C}: 0.10, \mathrm{Si}: 0.35, \mathrm{Mn}: 0.62, \mathrm{Cr}$ : 13.10) are shown in Table 2. The ratio of the gas volumes extracted in the latter $10 \mathrm{~min}$. of reaction to the total extraction amount in $30 \mathrm{~min}$. is given in Table 3.

From the tables it is known that the carbon monoxide extraction was completed some $95 \%$ in the first $20 \mathrm{~min}$. but for nitrogen an additional $10 \mathrm{~min}$. and more were required to recover the vacuum degree to the same level as that when the sample had not yet been charged. The residue of nitrogen was increased remarkably in order of analyses and for the 4th specimen $18 \%$ of the whole nitrogen volume was extracted in the last $10 \mathrm{~min}$.

(2) For the sake of revealing the variation of nitrogen values in the run of analyses, some series of standard sample No. 1 (S35C) were used and nitrogen extraction for each specimen was performed for $15 \mathrm{~min}$., which is three times as long as in the ordinary one, with the
Table 2. Components of the gas extracted in the last $10 \mathrm{~min}$. of a reaction period. $(13 \mathrm{Cr}$-steel)

(Unit: $\mathrm{ml} / \mathrm{g}$ of specimen)

\begin{tabular}{c|c|c|c|c}
$\begin{array}{c}\text { Order of } \\
\text { analysis }\end{array}$ & 1 & 2 & 3 & 4 \\
\hline Component & 0.003 & 0.006 & 0.013 & 0.019 \\
\hline Total & 0.092 & 0.004 & 0.007 & 0.010 \\
\hline $\mathrm{N}_{2}$ & 0 & 0.001 & 0.004 & 0.005 \\
\hline $\mathrm{CO}$ & 0.001 & 0.001 & 0.002 & 0.004 \\
\hline $\mathrm{H}_{2}$ & & &
\end{tabular}

Note: Each data is the average of the 10 time analyses.

Table 3. Ratio of the gas extracted in the last $10 \mathrm{~min}$. of a reaction period to the total extraction amount. (13Cr-steel)

\begin{tabular}{|c|c|c|c|c|}
\hline $\begin{array}{cl}\text { Order of } & \text { analysis } \\
\text { Component } & \end{array}$ & 1 & 2 & 3 & 4 \\
\hline Total & 2.1 & 3.6 & 6.6 & 10.1 \\
\hline $\mathrm{N}_{2}$ & 3.9 & 8.6 & 12.8 & 18.0 \\
\hline $\mathrm{CO}$ & 0.5 & 0.5 & 2.2 & 5.8 \\
\hline $\mathrm{H}_{2}$ & 3.2 & 7.7 & 10.1 & 20.3 \\
\hline
\end{tabular}

Note: Each data is the average of the 10 time analyses.

const. vol. press. measuring type apparatus. From the results shown in Fig. 3, even the first specimen gave a lower value than that obtained by chemical (Kjeldahl) method and in accordance with the order of the introduction of the sample nitrogen values were decreased, and that tendency was agreed with the experiences by I. Ogahara et ali. ${ }^{6}$ ) with respect to $18-8$ stainless steel.

(3) The blank values with the const. vol. press. measuring type apparatus were measured on the standard carbon steel No. 1, and ordinary samples of 
medium Cr, V, Mo and high Cr alloy steels whose chemical compositions are shown in Table 4.

The compositions of blank gases collected for 15 min., as long as the extraction time, after several continuous analyses of these specimens, were plotted in Fig. 4. In the diagram the $1 \mathrm{~mm}$ height of oil manometer was equal to $0.0058 \mathrm{Nm} l$ of gases. Following in the order of specimen charge the blank values were increased and were especially remarkable for steels containing $\mathrm{Cr}, \mathrm{V}$ and Mo. Hydrogen and carbon monoxide gases so scarcely increased that they hardly influenced the determination of each value of the components, but on the contrary, nitrogen rose

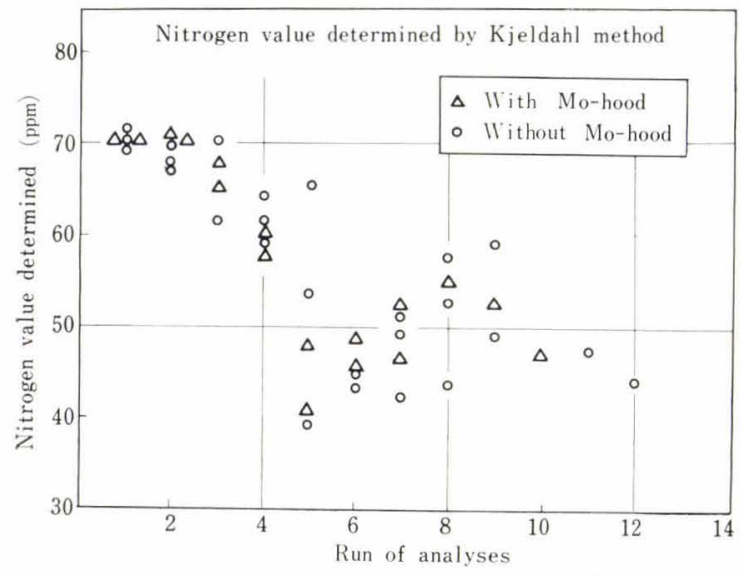

Fig. 3. Influence of a run of analyses on the nitrogen value determination. (C-steel) so remarkably up with the progress of sample charging that most part of blank gases was taken up by nitrogen. But distinct differences in the increase of nitrogen were observed by kind of steel. Namely, in order of $18 \mathrm{Cr}$ steel, $13 \mathrm{Cr}$ steel, medium $\mathrm{Cr}-\mathrm{V}-\mathrm{Mo}$ alloy and plain carbon steel increase of nitrogen gas was large and it was gradually collected even after the sample extraction time which was three times as long as in the ordinary analysis, because of the incomplete dissociation and release from the molten bath with the interferences of $\mathrm{Cr}, \mathrm{V}$ and Mo. Consequently, nitrogen values for each steel were determined low.

(4) Comparison of nitrogen values of the standard samples determined by the vacuum fusion method and chemical (Kjeldahl) method is described in Table 5. It was recognized that the former gave lower values in both the const. press. Orsat type and the const. vol. press. measuring type apparatus. This is considered due to the fact that the nitrogen in the specimen was incompletely extracted as shown in Tables 2 and 3 and remained partly in the metals in the graphite crucible.

Thus it would not be proper to regard the nitrogen values of many kinds of steels obtained by the vacuum fusion method accurate, so far as the present apparatus and analytical conditions are used.

\section{Extraction of Carbon Monoxide}

On the carbon monoxide extraction by the vacuum

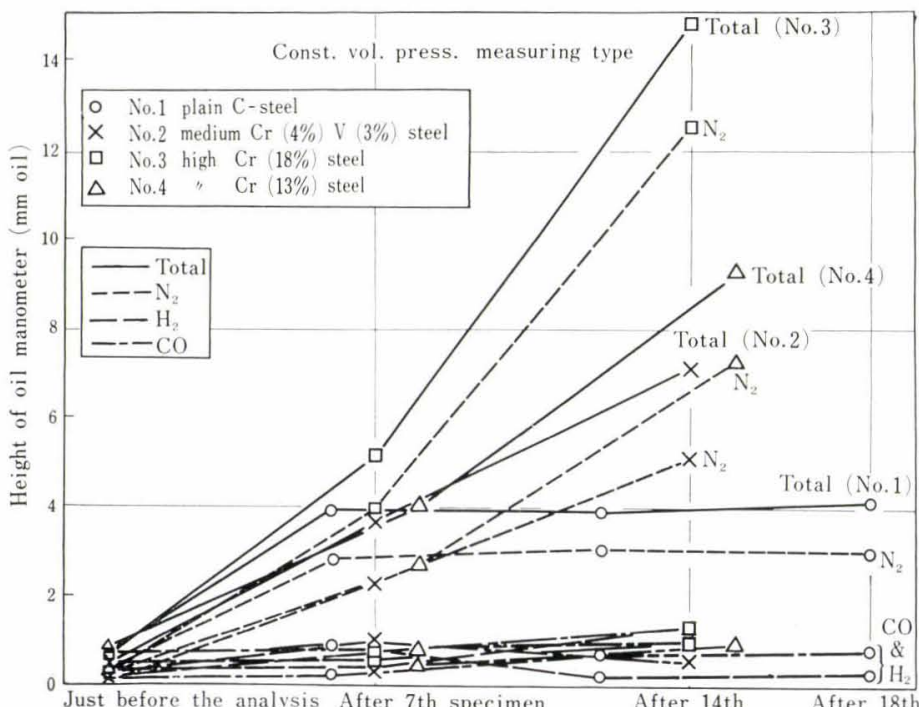

Fig. 4.

Variations of blank gas composition according to a run of analyses

Table 4. Chemical composition of the ordinary samples used for brank test

\begin{tabular}{|c|c|c|c|c|c|c|c|c|c|c|c|c|c|c|}
\hline & Spec. & $\begin{array}{l}\text { Type of } \\
\text { steel }\end{array}$ & $\mathrm{C}$ & $\mathrm{Si}$ & Mn & $\mathrm{P}$ & s & $\mathrm{Ni}$ & $\mathrm{Cr}$ & Mo & W & V & $\mathrm{Cu}$ & $\mathrm{Co}$ \\
\hline No. 1 & $\mathrm{~S} 35 \mathrm{C}$ & $\begin{array}{l}\text { Plain } \\
\text { C-steel }\end{array}$ & $\stackrel{0.30}{\sim 0.40}$ & $\stackrel{0.15}{\sim 0.35}$ & $\stackrel{0.60}{\sim 0.85}$ & $\begin{array}{l}0.030 \\
\max .\end{array}$ & $\begin{array}{l}0.030 \\
\text { max. }\end{array}$ & $\begin{array}{l}0.25 \\
\text { max. }\end{array}$ & $\begin{array}{l}0.20 \\
\max .\end{array}$ & & & & $\begin{array}{l}0.30 \\
\text { max. }\end{array}$ & \\
\hline \multirow{2}{*}{ No. 2} & SKH3 & \multirow{2}{*}{$\begin{array}{l}\text { Medium } \\
\text { Cr-, V-and } \\
\text { Mo-steel }\end{array}$} & $\stackrel{0.70}{\sim 0.85}$ & $\begin{array}{l}0.35 \\
\max .\end{array}$ & $\begin{array}{l}0.60 \\
\max .\end{array}$ & ", & $"$ & & $\begin{array}{l}3.50 \\
\sim 4.50\end{array}$ & & $\begin{array}{l}17.00 \\
\sim 19.00\end{array}$ & $\begin{array}{l}0.80 \\
\sim 1.20\end{array}$ & & \multirow{2}{*}{$\stackrel{4.50}{\sim 5.50}$} \\
\hline & SKH9 & & $\begin{array}{l}0.75 \\
\sim 0.90\end{array}$ & $\begin{array}{l}0.35 \\
\max .\end{array}$ & $\begin{array}{l}0.60 \\
\max .\end{array}$ & ", & $"$ & & $\stackrel{3.50}{\sim 4.50}$ & $\stackrel{4.00}{\sim 6.00}$ & $\stackrel{6.00}{\sim 7.00}$ & $\stackrel{1.80}{\sim 2.30}$ & & \\
\hline No. 3 & SuS27 & $\begin{array}{l}\text { High } \\
\text { Cr-steel }\end{array}$ & $\begin{array}{l}0.08 \\
\text { max. }\end{array}$ & $\begin{array}{l}1.00 \\
\text { max. }\end{array}$ & $\begin{array}{l}2.00 \\
\max .\end{array}$ & $\begin{array}{l}0.040 \\
\max .\end{array}$ & $\begin{array}{l}0.030 \\
\text { max. }\end{array}$ & $\begin{array}{l}8.00 \\
\sim 11.00\end{array}$ & $\begin{array}{l}18.00 \\
\sim 20.00\end{array}$ & & & & & \\
\hline \multirow{2}{*}{ No. 4} & SuS21 & \multirow{2}{*}{$\begin{array}{l}\text { High } \\
\text { Cr-steel }\end{array}$} & $\begin{array}{l}0.12 \\
\text { max. }\end{array}$ & $\begin{array}{l}0.75 \\
\max .\end{array}$ & $\begin{array}{l}1.00 \\
\max .\end{array}$ & $\begin{array}{l}0.040 \\
\max \text {. }\end{array}$ & $\begin{array}{l}0.030 \\
\text { max. }\end{array}$ & & $\begin{array}{l}12.00 \\
\sim 14.00\end{array}$ & & & & \multirow[b]{2}{*}{$\begin{array}{l}0.25 \\
\max \text {. }\end{array}$} & \\
\hline & SKD11 & & $\stackrel{1.40}{\sim 1.60}$ & $\begin{array}{l}0.40 \\
\text { max. }\end{array}$ & $\begin{array}{l}0.50 \\
\text { max. }\end{array}$ & $\begin{array}{l}0.030 \\
\max \text {. }\end{array}$ & $\begin{array}{l}0.030 \\
\max .\end{array}$ & $\begin{array}{l}0.50 \\
\text { max. }\end{array}$ & $\begin{array}{l}11.00 \\
\sim 13.00\end{array}$ & $\stackrel{0.80}{\sim 1.20}$ & & $\begin{array}{l}0.20 \\
\sim 0.50\end{array}$ & & \\
\hline
\end{tabular}


Table 5. Comparison of nitrogen values determined by the chemical (Kjeldahl) and the vacuum fusion methods $\left(n^{*}=6 \sim 20\right)$

\begin{tabular}{|c|c|c|c|c|c|c|}
\hline \multirow{2}{*}{\multicolumn{3}{|c|}{ Chemical (Kjeldahl) }} & $\underset{\text { permaloy-50 }}{\text { No. }{ }^{2}}$ & $\mathrm{No}_{\mathrm{S} 35 \mathrm{C}}^{3}$ & $\begin{array}{l}\text { No. } 4 \\
\text { SuS27 }\end{array}$ & ${ }_{\text {En15 }}^{\text {No. } 5}$ \\
\hline & & & $30 \mathrm{ppm}$ & 80 ppm & $337 \mathrm{ppm}$ & $105 \mathrm{ppm}$ \\
\hline \multirow{4}{*}{$\begin{array}{l}\text { Vacuum } \\
\text { fusion }\end{array}$} & \multirow{2}{*}{$\begin{array}{l}\text { Const. vol. } \\
\text { press. measuring }\end{array}$} & Mo-hood used & 17.7 & 58.0 & 328.3 & 30.7 , \\
\hline & & ", not used & 19.3, & 54.0 & 274.6 & $33.4 \quad$, \\
\hline & \multirow{2}{*}{$\begin{array}{l}\text { Const. press. } \\
\text { Orsat }\end{array}$} & Mo-hood used & - & 45.2, & - & 11.8, \\
\hline & & , not used & - & 37.1, & - & $27.4 \quad$, \\
\hline
\end{tabular}

* $n$ : the number of tests repeated.

fusion method the interference by $\mathrm{Al}$ and $\mathrm{Mn}$ has been well-known but the quantitative relations have not yet been clarified in the literatures. Accordingly the authors studied this problem, and at the same time the problems on the carbon monoxide gas adsorption by the metallic film deposited on the inner surface of the furnace tube and lowering of the oxygen determination values were investigated in detail, because there are many obscure points concerning them.

i. Temperature Measurements at the Inner Wall of the Furnace Tube and the Mo-Hood

It is said that carbon monoxide adsorbing temperature is in the range of $300^{\circ} \sim 500^{\circ} \mathrm{C}^{1), 2), 13)}$. The temperatures at the inner wall area, on which most of the condensed film was deposited, and at the Mo-hood covered at the top of the quartz tube were measured with the const. press. Orsat type apparatus. As shown in Fig. 5, Pt-Pt. Rh couple, corrected for the influence of high frequency induction heater, was sealed in the vacuum apparatus through the branch tube end so as to touch the inner wall by the tip.

On the Mo-hood, the Tempilstik (a sort of crayon) of $899^{\circ}$ and $927^{\circ} \mathrm{C}$ were painted on the surface and the temperature when it melted was regarded as to have reached the specified degree. In Tables 6 and 7, the relations between the crucible temperature which were measured by the optical pyrometer, and temperature of the inner surface of the furnace tube or the Mo-hood are presented. It is apparent from Table 6, that when the crucible reached analytical condition of $1,850^{\circ} \mathrm{C}$, the temperature of the inner surface of the furnace tube where the condensed film was thickest, was $300^{\circ} \sim 500^{\circ} \mathrm{C}$, that is carbon monoxide adsorption temperature. In other words, the temperatures were $450^{\circ} \sim 550^{\circ} \mathrm{C}$ with Mo-hood, $520^{\circ} \mathrm{C}$ without it and $330^{\circ}$

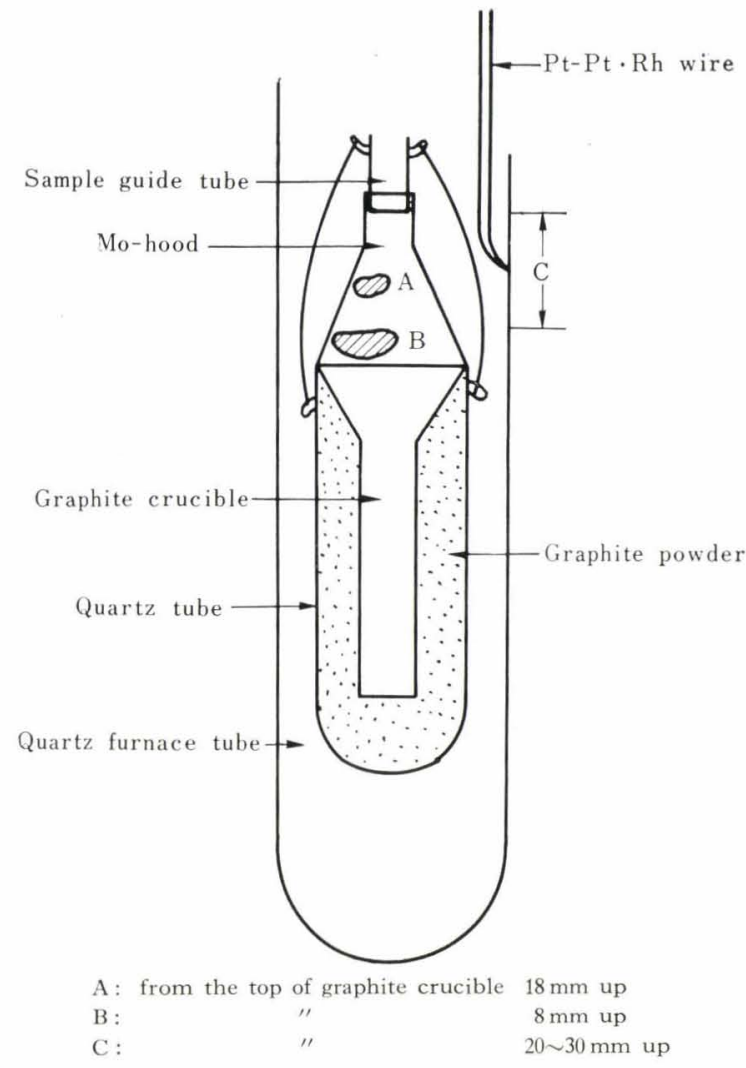

Fig. 5. Temperature measured positions at the furnace tube and the Mo-hood

Table 6. Temperature of the crucible and the inner wall of the furnace tube

\begin{tabular}{|c|c|c|c|c|c|c|c|c|c|}
\hline \multirow[b]{3}{*}{$T\left({ }^{\circ} \mathrm{C}\right)$} & & \multicolumn{8}{|c|}{ Temp. of the inner wall of the furnace tube $\left({ }^{\circ} \mathrm{C}\right)$} \\
\hline & K & \multicolumn{2}{|c|}{ Mo-hood } & \multicolumn{5}{|c|}{ Quartz hood } & \multirow{2}{*}{$\begin{array}{l}\text { Non } \\
30 \text { up }\end{array}$} \\
\hline & $M(\mathrm{~mm})$ & 20 up & 30 up & 20 up & 20 up & 30 up & 30 up & 35 up & \\
\hline & 2,330 & 646 & 515 & 559 & 540 & 458 & 423 & 405 & 660 \\
\hline & 1,850 & 555 & 434 & 470 & 430 & 365 & 335 & 325 & 520 \\
\hline
\end{tabular}

$K$ : kind of hood, $M$ : measured position at the inner wall, $T$ : temp. of the crucible.

Table 7. Temperatures of the crucible and the Mo-hood

\begin{tabular}{|c|c|c|c|c|c|c|}
\hline & & & \multicolumn{2}{|c|}{ New Mo-hood } & \multicolumn{2}{|c|}{ Old Mo-hood* } \\
\hline \multicolumn{3}{|c|}{ Temp. of the Mo-hood (m.p. of Tempilstik) $\left({ }^{\circ} \mathrm{C}\right)$} & 899 & 927 & 899 & 927 \\
\hline \multirow{2}{*}{ Temp. of the crucible** $\left({ }^{\circ} \mathrm{C}\right)$} & \multirow{2}{*}{$\begin{array}{l}\text { Distance from the top of the crucible. } \\
\text { (Tempilstik painted position) }\end{array}$} & $\int 18 \mathrm{~mm}$ up & 1,540 & 1,720 & 1,425 & 1,560 \\
\hline & & $8 \mathrm{~mm}$ up & 1,395 & 1,640 & 1,285 & 1,380 \\
\hline
\end{tabular}

* After 5 6 times use. ** When the Tempilstik on the Mo-hood is melted. 
$\sim 470^{\circ} \mathrm{C}$ with quartz hood, at the position of inner surface of the tube $20 \sim 30 \mathrm{~mm}$ up from the rim of the crucible. From Table 7, it is said that if the temperature of the crucible is maintained at $1,850^{\circ} \mathrm{C}$, the temperature of the Mo-hood would exceed $900^{\circ} \mathrm{C}$, which is far higher than the carbon monoxide adsorption temperature.

ii. Influences of $\mathrm{Al}$ and $\mathrm{Mn}$ on the Pure Iron and Common Steels

The capsule shaped pure iron specimens enclosing $\mathrm{Al}$ or $\mathrm{Mn}$ were analysed to examine the effect of such an element. When these were introduced into the graphite crucible at $1,850^{\circ} \mathrm{C}, \mathrm{Al}$ or $\mathrm{Mn}$ was molten and mixed simultaneously with the iron whereby similar reactions were expected as to the steel samples of various contents. On the several kinds of steels with the different $\mathrm{Al}$ or $\mathrm{Mn}$ contents, the effect of the Mohood and the conditions of the metallic film formation were studied. Chemical compositions and mean oxygen values of the pure iron and the standard steels in the authors' laboratory are shown in Table 8.

Experimental results of oxygen determination were obtained with the pure iron samples respectively in the case of $\mathrm{Al}$ or $\mathrm{Mn}$ addition up to $1.5 \%$ and at the same time the advantage of the Mo-hood attached to the quartz tube was investigated. The number of specimens continuously analysed for each content werel1 15 by the const. vol. press. measuring type apparatus, and 4 by the const. press. Orsat type one. Thus the average oxygen values were illustrated in Figs. 6 and 7, relating with each rate of $\mathrm{Al}$ or $\mathrm{Mn}$ addition. In spite of the different apparatus adopted, $\mathrm{Al}$ or $\mathrm{Mn}$ contained samples showed the reverse tendency of a decrease in the oxygen values with the increase of such an element. Only $40 \%$ of the oxygen standard value with $1 \%$ of $\mathrm{Mn}$ addition and $35 \%$ of it with $1.5 \%$ of $\mathrm{Al}$ were obtained. The curve of $1,700^{\circ} \mathrm{C}$ in Fig. 6 gave a little higher value because of the higher carbon monoxide evolving speed by the faster reaction. The Mo-hood, as seen in these diagrams, considerably prevented the interference of $\mathrm{Al}$ or $\mathrm{Mn}$ on the carbon monoxide extraction. The decrease of evaporated metal deposits was visually observed in the case of Mo-hood being used. This is considered most of the metallic vapors expelled from the graphite crucible condensed on the Mo-hood and only a little on the inner wall of the furnace tube, which resulted in the improvement of carbon monoxide extraction.

Thus, the carbon monoxide adsorption on the condensed metallic film of the furnace tube was certainly recognized as reported hitherto. The effect of Mo-

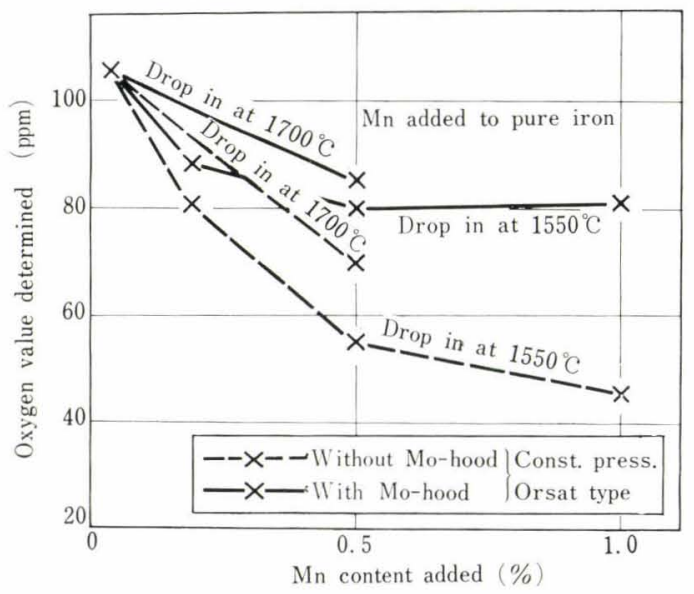

Fig. 6. Influence of $\mathrm{Mn}$ addition on the oxygen value determination

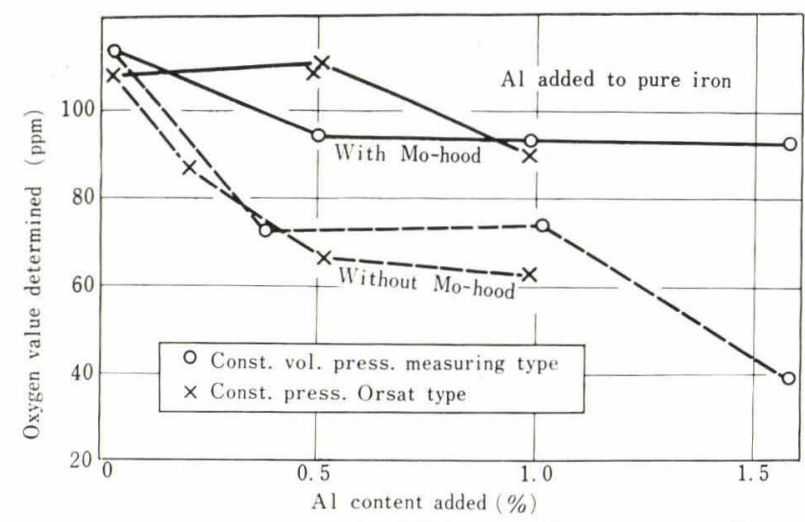

Fig. 7. Influence of $\mathrm{Al}$ addition on the oxygen value determination

Table 8. Chemical composition of the specimens

\begin{tabular}{|c|c|c|c|c|c|c|c|c|c|c|c|c|}
\hline No. & Spec. & $\begin{array}{l}\mathrm{C} \\
(\%)\end{array}$ & $\begin{array}{c}\mathrm{Si} \\
(\%)\end{array}$ & $\begin{array}{l}\text { Mn } \\
(\%)\end{array}$ & $\begin{array}{l}\mathrm{P} \\
(\%)\end{array}$ & $\begin{array}{c}\mathrm{S} \\
(\%)\end{array}$ & $\begin{array}{c}\mathrm{Ni} \\
(\%)\end{array}$ & $\begin{array}{l}\mathrm{Cr} \\
(\%)\end{array}$ & $\begin{array}{l}\mathrm{Cu} \\
(\%)\end{array}$ & $\begin{array}{c}\mathrm{A} 1 \\
(\%)\end{array}$ & $\begin{array}{r}\mathrm{Fe} \\
(\%)\end{array}$ & $\begin{array}{c}\mathrm{O} \text { (ppm) } \\
\text { (Mo-hood used) }\end{array}$ \\
\hline 1 & Pure Fe & 0.01 & 0.08 & 0.03 & 0.007 & 0.011 & 0.02 & $\operatorname{tr}$. & 0.01 & 0.016 & & $\begin{array}{ll}* & 110.2(\sigma=4.34) \\
\circ & 107.3(\sigma=7.45)\end{array}$ \\
\hline 2 & $\begin{array}{l}50 \% \mathrm{Ni} \\
\text { permalloy }\end{array}$ & 0.006 & 0.05 & 0.21 & 0.003 & 0.004 & 50.04 & tr. & $\operatorname{tr}$ & 0.010 & & * $196.9(\sigma=6.58)$ \\
\hline 3 & $\mathrm{~S} 35 \mathrm{C}$ & 0.39 & 0.29 & 0.70 & 0.008 & 0.009 & 0.08 & 0.09 & 0.17 & 0.029 & & $\begin{array}{lll}* & 50.9 & (\sigma=1.93) \\
\circ & 47.4 & (\sigma=5.62)\end{array}$ \\
\hline 4 & SuS27 & 0.06 & 0.79 & 1.24 & 0.014 & 0.017 & 9.63 & 19.24 & 0.06 & 0.039 & & $* 60.7(\sigma=5.26)$ \\
\hline 5 & En15 & 0.44 & 0.30 & 1.44 & 0.016 & 0.019 & & & 0.17 & 0.030 & & $\begin{array}{l}* \quad 21.7(\sigma=1.40) \\
\circ \quad 15.0(\sigma=2.82)\end{array}$ \\
\hline 6 & Pure Fe & 0.01 & 0.01 & tr. & 0.002 & 0.010 & 0.04 & 0.01 & & 0.018 & & $\circ 713.7(\sigma=5.05)$ \\
\hline & Elect. Mn & 0.010 & tr. & 99.92 & 0.002 & 0.028 & & & & & 0.018 & \\
\hline & $\mathrm{Al}$ & & & & & & & & & $>99.9$ & & \\
\hline
\end{tabular}

* Const. vol. press. measuring type. - Const. press. Orsat type. 
Table 9. Influence of $\mathrm{Al}$ on the oxygen value determined. (Effect of Mo-hood)

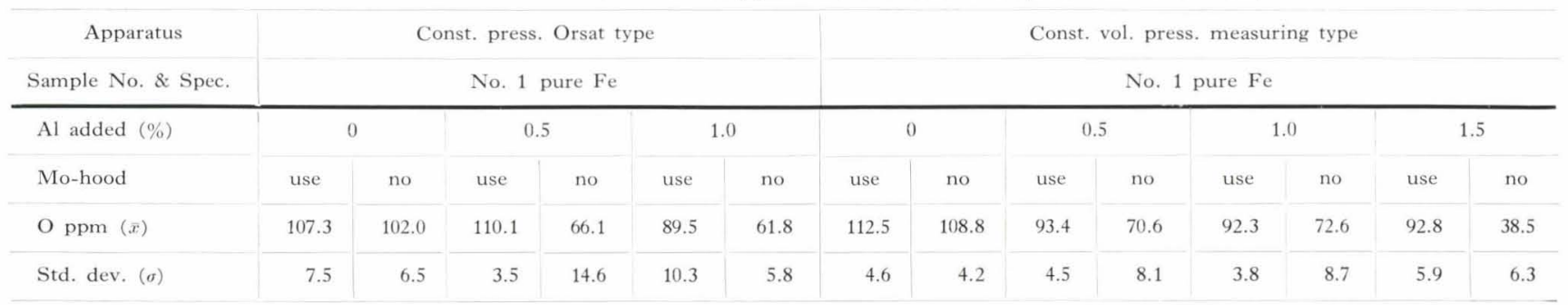

Table 10. Influence of Mn on the oxygen value determined. (Effect of Mo-hood)

\begin{tabular}{|c|c|c|c|c|c|c|c|c|c|c|c|c|c|c|c|c|c|c|c|c|c|c|c|c|c|c|}
\hline Apparatus & \multicolumn{16}{|c|}{ Const. press. Orsat type } & \multicolumn{10}{|c|}{ Const. vol. press. measuring type } \\
\hline $\begin{array}{l}\text { Sample No. } \\
\& \text { spec. }\end{array}$ & \multicolumn{8}{|c|}{ No. 1 pure $\mathrm{Fe}$} & \multirow{2}{*}{\multicolumn{2}{|c|}{$\frac{\begin{array}{l}\text { No. }{ }^{3} \\
\text { S35 C }\end{array}}{0.70}$}} & \multirow{2}{*}{\multicolumn{2}{|c|}{$\frac{\begin{array}{l}\text { No. } 5 \\
\text { En15 }\end{array}}{1.44}$}} & \multicolumn{4}{|c|}{$\begin{array}{l}\text { No. } 6 \\
\text { pure Fe }\end{array}$} & \multirow{2}{*}{\multicolumn{2}{|c|}{$\begin{array}{c}\begin{array}{c}\text { No. } \\
\text { pure }\end{array} \\
0\end{array}$}} & \multirow{2}{*}{\multicolumn{2}{|c|}{$\frac{\begin{array}{c}\text { No. }{ }^{2} \\
\text { permalloy }\end{array}}{0.21}$}} & \multirow{2}{*}{\multicolumn{2}{|c|}{$\frac{\begin{array}{l}\text { No. } 3 \\
\text { S35. C }\end{array}}{0.70}$}} & \multirow{2}{*}{\multicolumn{2}{|c|}{$\frac{\begin{array}{c}\text { No. } 4 \\
\text { SuS27 }\end{array}}{1.24}$}} & \multirow{2}{*}{\multicolumn{2}{|c|}{$\frac{l_{\text {No. }}{ }^{5}}{1.44}$}} \\
\hline $\operatorname{Mn}(\%)$ & \multicolumn{2}{|c|}{0} & \multicolumn{2}{|c|}{$(0.2)^{*}$} & \multicolumn{2}{|c|}{$(0.5)^{*}$} & \multicolumn{2}{|c|}{$(1.0)^{*}$} & & & & & \multicolumn{2}{|c|}{0} & \multicolumn{2}{|c|}{$(0.05)^{*}$} & & & & & & & & & & \\
\hline Mo-hood & use & no & use & no & use & no & use & no & use & no & use & no & use & no & use & no & use & no & use & no & use & no & use & no & use & no \\
\hline $\mathrm{O}(\mathrm{ppm})(\bar{x})$ & 107.3 & 102.0 & 88.8 & 81.5 & 80.1 & 55.0 & 82.3 & 45.5 & 49.3 & 29.6 & 15.0 & 6.2 & 713.7 & 718.0 & 711.2 & 694.7 & 112.5 & 108.8 & 193.0 & 186.0 & 50.9 & 30.2 & 60.7 & 29.5 & 21.7 & 8.7 \\
\hline Std. dev. ( $(\sigma)$ & 7.5 & 6.5 & 11.1 & 10.8 & 13.5 & 13.8 & 2.1 & 3.2 & 1.8 & 0.7 & 2.8 & 3.5 & 5.1 & 6.7 & 3.5 & 7.9 & 4.6 & 4.2 & 6.6 & 8.5 & 1.9 & 3.2 & 5.3 & 6.2 & 1.1 & 3.4 \\
\hline
\end{tabular}

* The case of Mn addition.

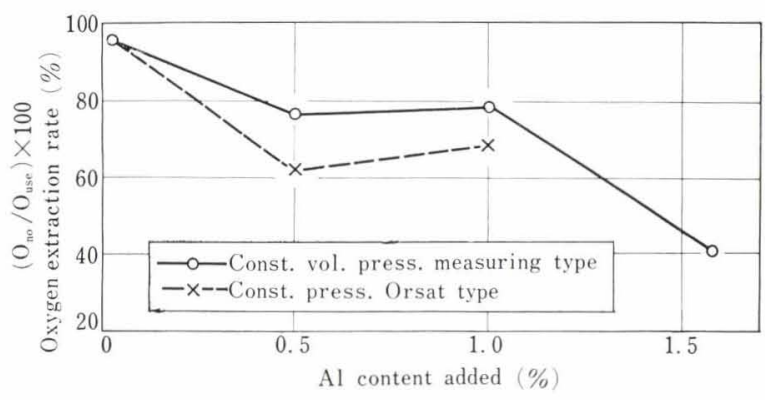

Fig. 8. Effect of $\mathrm{Al}$ content on oxygen extraction rate. (Comparison in the case of Mo-hood being used and being not used)

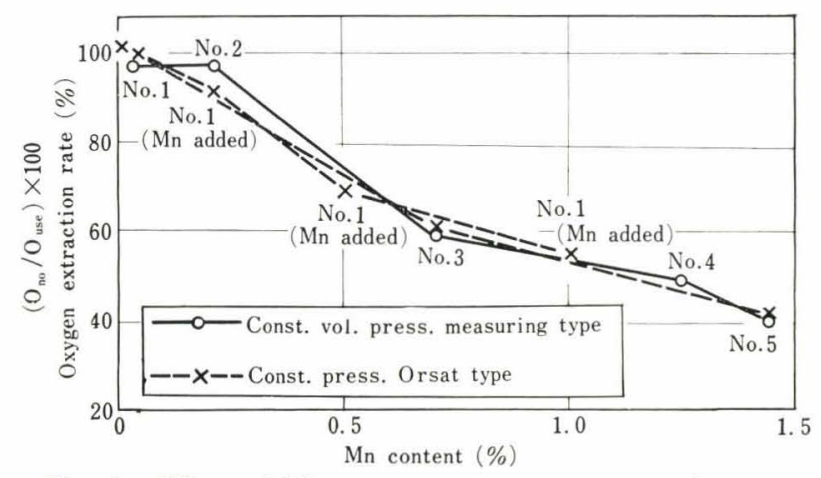

Fig. 9. Effect of Mn content on oxygen extraction rate. (Comparison in the case of Mo-hood being used and being not used)

hood, still, was not enough to revive $100 \%$ of the oxygen content of the pure iron in the case of $\mathrm{Al}$ or $\mathrm{Mn}$ addition. The analytical values either with or without Mo-hood were compared with several specimens with addition of $\mathrm{Al}$ or $\mathrm{Mn}$, which are shown in Tables 9 and 10 .

To obtain the influence of $\mathrm{Al}$ or $\mathrm{Mn}$ quantitatively, the rate of the values without Mo-hood against those with it was computed.

Oxygen extraction rate $=\mathrm{O}_{\text {no }} / \mathrm{O}_{\text {use }} \times 100$

Where, $\mathrm{O}_{\mathrm{no}}$ : oxygen value determined without the Mo-hood $\mathrm{O}_{\text {use }}$ with

Relations between these data and the contents of $\mathrm{Al}$ or $\mathrm{Mn}$ are illustrated in Figs. 8 and 9. The reason of employing $\mathrm{O}_{\text {use }}$ as the basis is that, as previously mentioned, the accurate oxygen value was not obtained even with the use of Mo-hood and so the $\mathrm{O}_{\text {use }}$ values were used as a temporary basis of the calculation.

By Figs. 8 and 9, it is known that the effects of $\mathrm{Al}$ or $\mathrm{Mn}$ on the oxygen determination are quantitative and similar in both apparatus. As shown in Fig. 9 the influences of $\mathrm{Mn}$ on the capsule shaped pure iron and alloy steels were nearly equal unrelated to the kind of samples.

3. Relations among the Analytical Results of the Condensed Metallic Film and the Residual Metals in the Crucible and the Oxygen Values Determined

It was already described that there was a close relation between the oxygen values and the condensed metallic film deposited on the inner wall of the furnace tube. To study the details of this problem the composition of main components- $\mathrm{Fe}, \mathrm{Mn}$ and $\mathrm{Al}$ - was obtained by dissolving the film into acid solution after the gas analysis. In this experiment other metals were found negligible. At the same time on the residual metals in the graphite crucible, the quantities of remaining $\mathrm{Mn}$ and $\mathrm{Al}$ were determined. The analyses corresponding to each oxygen values in Tables 9 and 10 were performed and the results are shown in Tables 11 and 12.

From the evaporated quantity of the metals obtained by the results for residues in the crucible, it was realized that the higher the content or addition of $\mathrm{Mn}$ or $\mathrm{Al}$, the larger its evaporated quantity.

The evaporation unit of $\mathrm{Mn}$, which is equivalent to the evaporation quantity for a gram of the sample, is shown in Fig. 10 relating with $\mathrm{Mn}$ content. Of the Mn vaporization it was found that the evaporation unit was generally in proportion to the $\mathrm{Mn}$ content (or addition) regardless of the kinds of samples or the employment of the Mo-hood. The slightly lower lines with the use of Mo-hood were regarded due to its prevention of violent evaporation of $\mathrm{Mn}$. The $\mathrm{Al}$ evaporation was, as a whole, less than that of $\mathrm{Mn}$, 
Table 11. Analyses of condensed film on the inner wall of the furnace tube and residual metals in the graphite crucible. (Const. press. Orsat type)

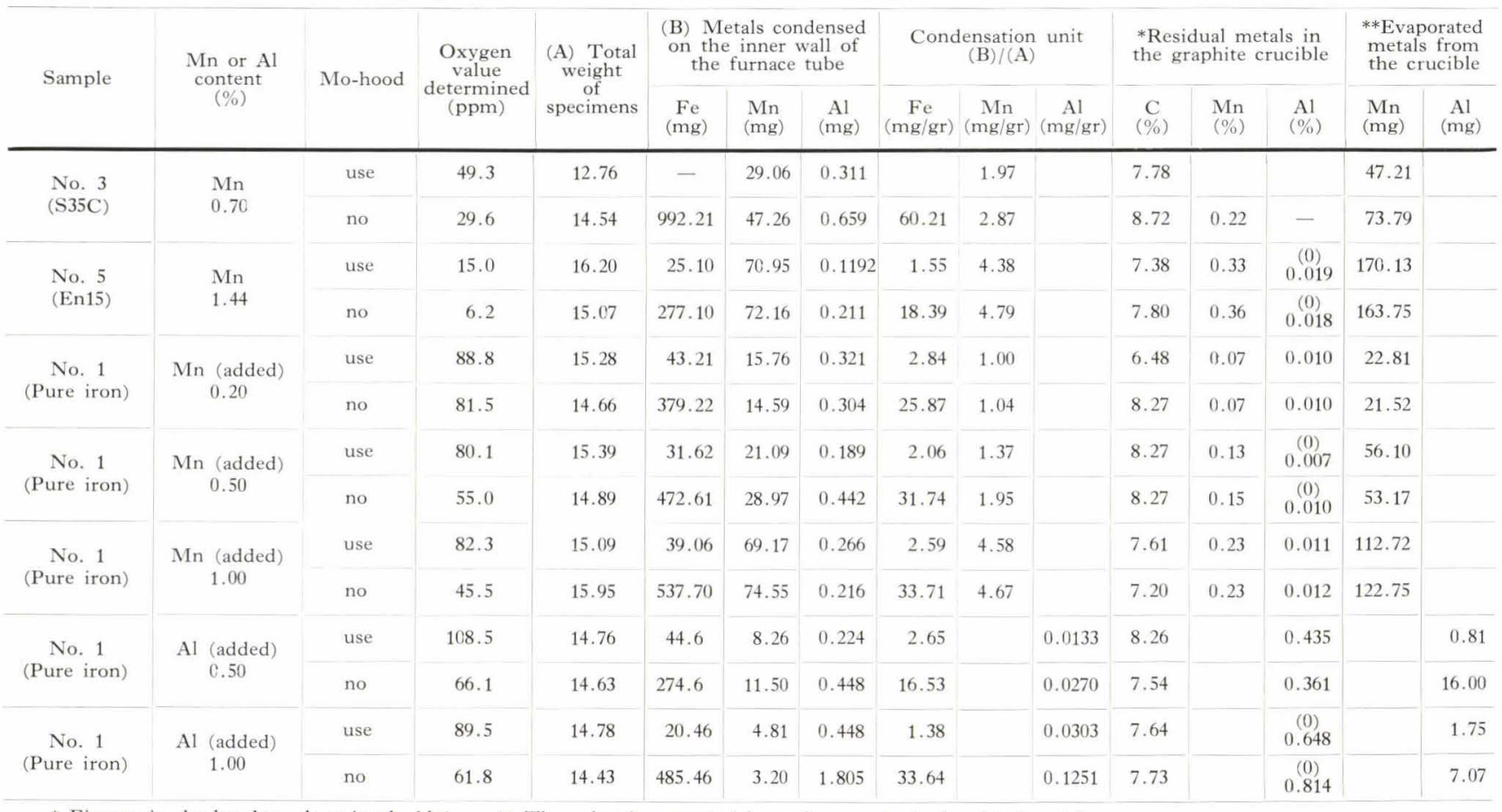

* Figures in the brackets show insol. Al\%. *** The value is corrected by carbon content of residual metals.

Table 12. Analyses of condensed film on the inner wall of the furnace tube and residual metals in the graphite crucible. (Const. vol. press. measuring type)

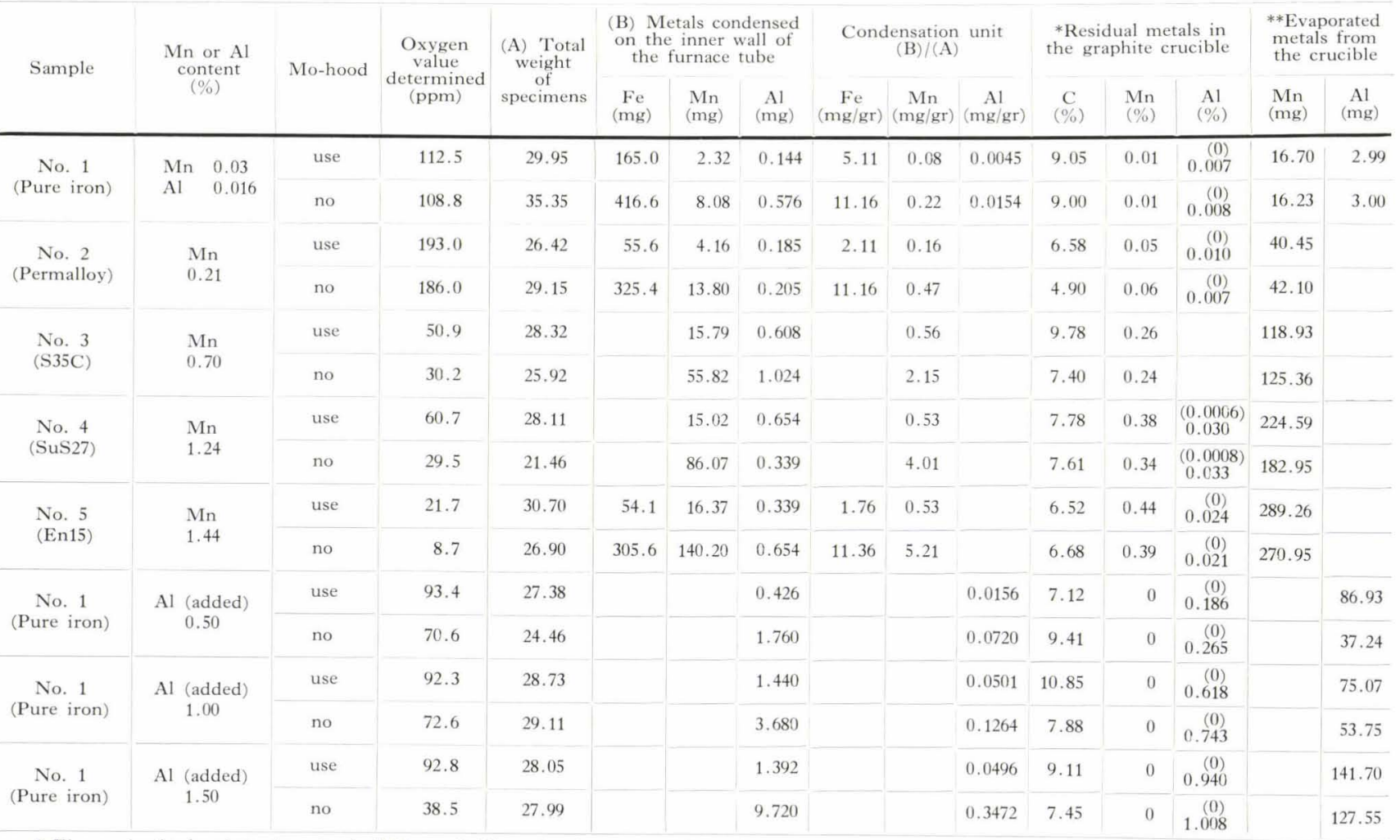

* Figures in the brackets show insol. Al\%. *** The value is corrected by carbon content of residual metals.

especially little in the const. press. Orsat type apparatus but with the const. vol. press. measuring type one the evaporation unit grew in proportion with the increase of $\mathrm{Al}$ content. But clear relation between $\mathrm{Al}$ evaporation amount and its content as well as method of its addition, its evaporation speed, etc. was not obtained.
Secondary, the authors investigated the analytical data of the condensed film, which was regarded as directly relating to oxygen determination. In the following considerations the condensed film on the Mohood was excluded since the temperature on its surface, when the analysis had been performed, had been over 


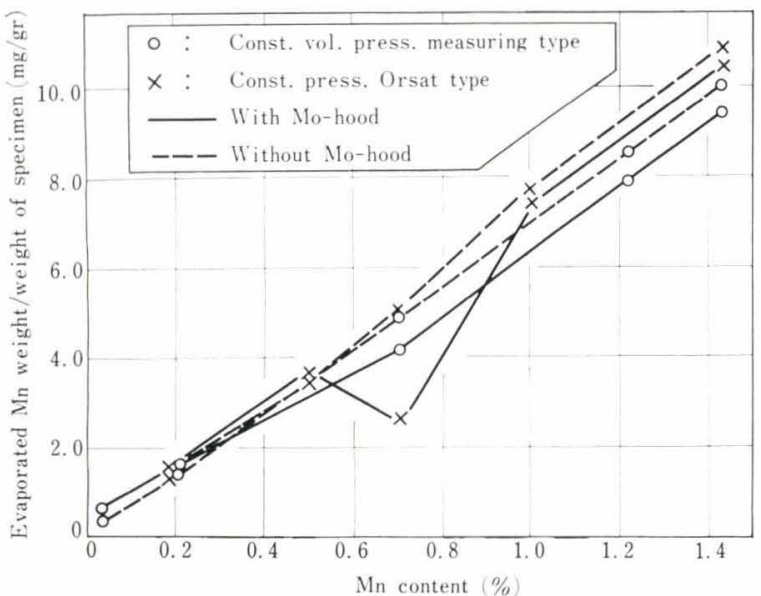

Fig. 10. Relation between Mn content and evaporated Mn weight

$900^{\circ} \mathrm{C}$ which was regarded as far higher than the carbon monoxide gas adsorption temperature. ${ }^{1), 2)}$ In accordance with the increase of the content of $\mathrm{Al}$ or $\mathrm{Mn}$ in the samples each quantity in the condensed film was increased. The $\mathrm{Al}$ condensation was less than that of $\mathrm{Mn}$ or $\mathrm{Fe}$ and particularly Fe condensation was large in both apparatus in the case of Mohood being not used. It was recognized that the Mohood was very effective for the reduction of the condensation of these metals on the inner surface of the furnace tube.

Now to get the relations with the oxygen values, the condensation rate, which was calculated dividing the condensation unit in the case of Mo-hood being not used (refer to the column of the condensation unit (B) $/(\mathrm{A})$ in Tables 11 and 12) by that with Mo-hood, was compared with the oxygen extraction rate.

Condensation rate $=$ Condensation unit $_{(\mathrm{no})}$ Condensation unit $_{(1 \mathrm{se})}$

Where, Condensation unit ${ }_{(\text {no) }}$ : condensed quantity for a gram of sample in the case of Mo-hood being not used Condensation unit (usc) $_{\text {: }}$ condensed quantity for a gram of sample in the case of Mo-hood being used

They were plotted in Figs. 11 and 12 relating with the oxygen extraction rate. In general a large oxygen extraction rate, regardless of the employment of Mohood, corresponds to a small metal condensation, consequently to approximate unity in the condensation rate. On the contrary, the reduction of oxygen extraction rate means the increase of metal condensation in the absence of Mo-hood, that is, higher condensation rate. At the same time there was some difference between the two apparatus. In the const. press. Orsat type apparatus the variation of $\mathrm{Al}$ or $\mathrm{Mn}$ condensation rate was small and unrelated to the oxygen extraction rate but that of $\mathrm{Fe}$ was very remarkable. Compared with each condensation unit in both apparatus in Tables 11 and 12, it is nearly equal for the specimens of the same content. So it is considered that in the const. press. Orsat type apparatus even when the Mo-hood was used $\mathrm{Al}$ or Mn was gathered on the surface of the furnace tube due to the conditions of the shape of Mo-hood, dis-

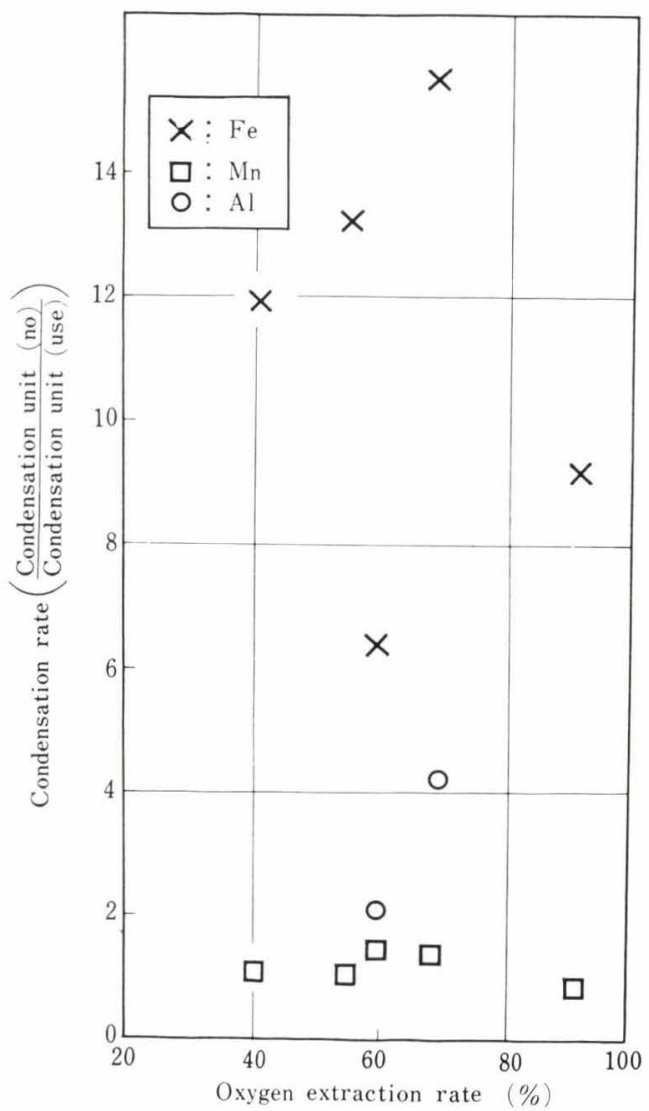

Fig. 11. Relation between $\mathrm{Fe}, \mathrm{Mn}, \mathrm{Al}$ condensation rates and oxygen extraction rate. (Const. press. Orsat type)

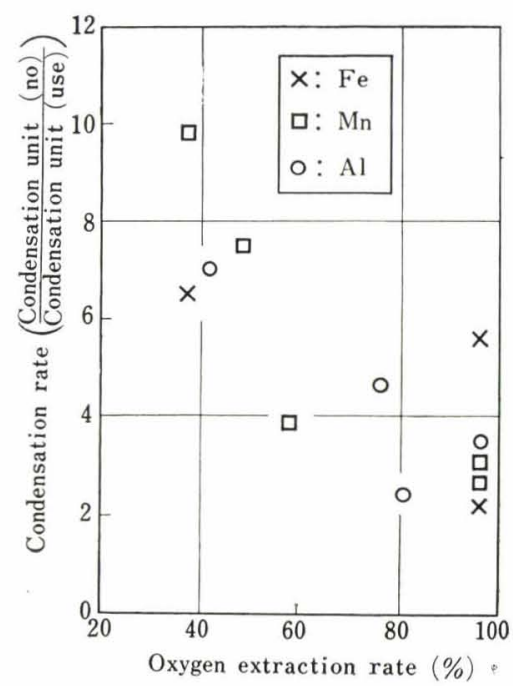

Fig. 12. Relation between $\mathrm{Fe}, \mathrm{Mn}, \mathrm{Al}$ condensation rates and oxygen extraction rate. (Const. vol. press. measuring type)

tance from the crucible, and extraction time. On the other hand, the relation of the oxygen extraction rate and the $\mathrm{Al}, \mathrm{Mn}$ and $\mathrm{Fe}$ condensation rates for the const. vol. press. measuring type apparatus is shown in Fig. 12, from which it can be said that the prevention of deposition of metal vapors was remarkable and carbon monoxide gas was extracted sufficiently with the use of Mo-hood. 


\section{Discussion}

\section{On the Extraction of Nitrogen}

(1) It was made clear that the nitrogen extraction was inadequate even for a carbon steel (refer to Fig. 3) and that it was far more difficult for steels containing some elements which increase the nitrogen solubility ${ }^{7), 10) \sim 12)}$, e.g. Cr, V, Mo, Mn, etc, under the present analytical conditions.

On this point, the reaction temperature, $1,850^{\circ} \mathrm{C}$, is distinctly a satisfactory condition for dissociating the nitrides in steels completely by the heat and the carbon as indicated in the calculations by Z. M. Turovtseva, et ali $^{7}$.

Thus it is considered that the nitrogen in molten steel does not exist as the nitrides which dissociate at low temperature but as the solute of the increased solubility which is caused by the activity coefficient lowered by $\mathrm{Cr}, \mathrm{V}$ and $\left.\mathrm{Mo}^{10} \sim 12\right)$ contained.

For example, quoting the research made by $\mathrm{S}$. Maekawa, et ali. on the influence of some elements on the nitrogen solubility in molten iron, it can be said that the increase of the following elements from 0 to $5 \%$ corresponds to the increase of nitrogen solubility from 400 to $1,500 \mathrm{ppm}$ for $\mathrm{V}, 400$ to $750 \mathrm{ppm}$ for $\mathrm{Cr}, 400$ to $500 \mathrm{ppm}$ for $\mathrm{Mn}$ and 400 to $480 \mathrm{ppm}$ for Mo respectively.

Consequently it is considered that the delay of nitrogen extraction results in the release of the gas, controlled only by the diffusion from the surface of the melt in the crucible to the vacuum vessel. There are of course several complex problems such as the violent boiling of carbon monoxide gas by the reaction of carbon and oxides, the solubility reduction of nitrogen by the dissolution of carbon from the graphite crucible accompanying the increase of viscosity, and the formation of a thin layer of viscous carbide at the upper part of molten metals, and therefore it may not be easy to make a decisive conclusion here.

(2) On the nitrogen adsorption by the condensed film of the inner surface of the furnace tube, no difference was seen either with the use of Mo-hood or without it as shown in Table 5. This is in accordance with other reports published ${ }^{7,9), 13), 19)}$.

(3) To obtain the accurate nitrogen content by the vacuum fusion method, the followings are considered. (a) The employment of a suitable flux or bath metal to promote the activity of nitrogen in the molten steel, which brings about an acceleration of gas exhaustion and the prevention of the increase of viscosity. (b) The improvement of the mercury diffusion pump to accelerate the diffusion of gases from the molten metal surface that is regarded as the rate determining step of the nitrogen extraction.

2. On the Extraction of Carbon Monoxide and the Effect of Mo-Hood

(1) It was ascertained that such elements as $\mathrm{Al}$ and $\mathrm{Mn}$ lowered the oxygen values in the experiments with pure iron to which these elements were added. It was made clear that the oxygen values were reduced with the increase of these interfering elements, and the quantitative relations between $\mathrm{Al}$ or $\mathrm{Mn}$ and the analytical values of oxygen, which has been indistinct hitherto, was caught to some degree. While a slight decrease in oxygen values was observed even in such a lower content of $\mathrm{Mn}$ as $0.03 \%$ and $0.05 \%$ for No. 1 and No. 7 samples of pure iron in Table 10.

(2) To interrupt the above-mentioned effect of $\mathrm{Al}$ or $\mathrm{Mn}$, the Mo-hood covered on the quartz tube indicated a considerable merit. Because of its imperfection, however, there remain some questions in obtaining the accurate oxygen content of steels containing such harmful elements by an ordinary analytical technique.

The temperature of the interior wall of the furnace tube rises up to the maximum carbon monoxide adsorption range ${ }^{1,2)}$ of $\mathrm{Fe}, \mathrm{Mn}$ and $\mathrm{Al}$ condensed film, $300^{\circ} \sim 500^{\circ} \mathrm{C}$, independently of the employment of Mohood. As for the Mo-hood it is over $900^{\circ} \mathrm{C}$ during analyses, therefore little adsorption by the deposited metals occurs. Accordingly, with the use of Mo-hood the formation of the condensed film on the furnace tube is decreased, which results in the extreme reduction of the adsorption reaction area, whereby the analytical results of oxygen is improved.

3. The Analytical Results of the Components of the Condensed Film and the Residual Metals in the Graphite Crucible

From the data obtained the following can be summarized:

(1) Between the improvement of oxygen value and the reduction of $\mathrm{Fe}, \mathrm{Mn}$, and $\mathrm{Al}$ - the components of the condensed film-some quantitative relations are conceived.

Thus when a sample contains $\mathrm{Mn}$ or $\mathrm{Al}$, the condensed film composed of $\mathrm{Fe}, \mathrm{Mn}$ and $\mathrm{Al}$ adsorbs the carbon monoxide gas extracted by reaction, whereby the oxygen value in analysis is lowered.

(2) Through the analysis of the residual metals in the graphite crucible which was performed in order to investigate the condensation mechanism of the metallic film on the inner surface of the furnace tube, it was known that large quantities of $\mathrm{Al}$ or $\mathrm{Mn}$ were vaporized and flown out. The quantity was proportional to its content in the case of $\mathrm{Mn}$. In some preliminary experiments, the condensation units and the evaporation units of Mn after the analyses of the first, second, and $n$th specimen respectively were found nearly constant and they were almost controlled by only the Mn content of the specimen. This is thought due to the molten metal bath being at a stationary state (a state on a half way to the equilibrium) at the end of the gas extraction of each specimen. Namely, evaporated quantity may be controlled by the vapor pressure, evaporation rate at the analytical temperature of $1,850^{\circ} \mathrm{C}$ and the content of each metal.

For references the evaporation rates and the vapor pressures of several metals are shown in Table 13.

From this table it is understood that vapor pressures of $\mathrm{Mn}$ and $\mathrm{Al}$ are extremely high and their vaporizations are very active at analytical temperature. The evaporation rate at $1,850^{\circ} \mathrm{C}$ in the table is calculated by Z. M. Turovtseva's equation ${ }^{7)}$ insert- 
Table 13. Vapor pressures and evaporation rates of various metals ${ }^{6) \sim 9)}$

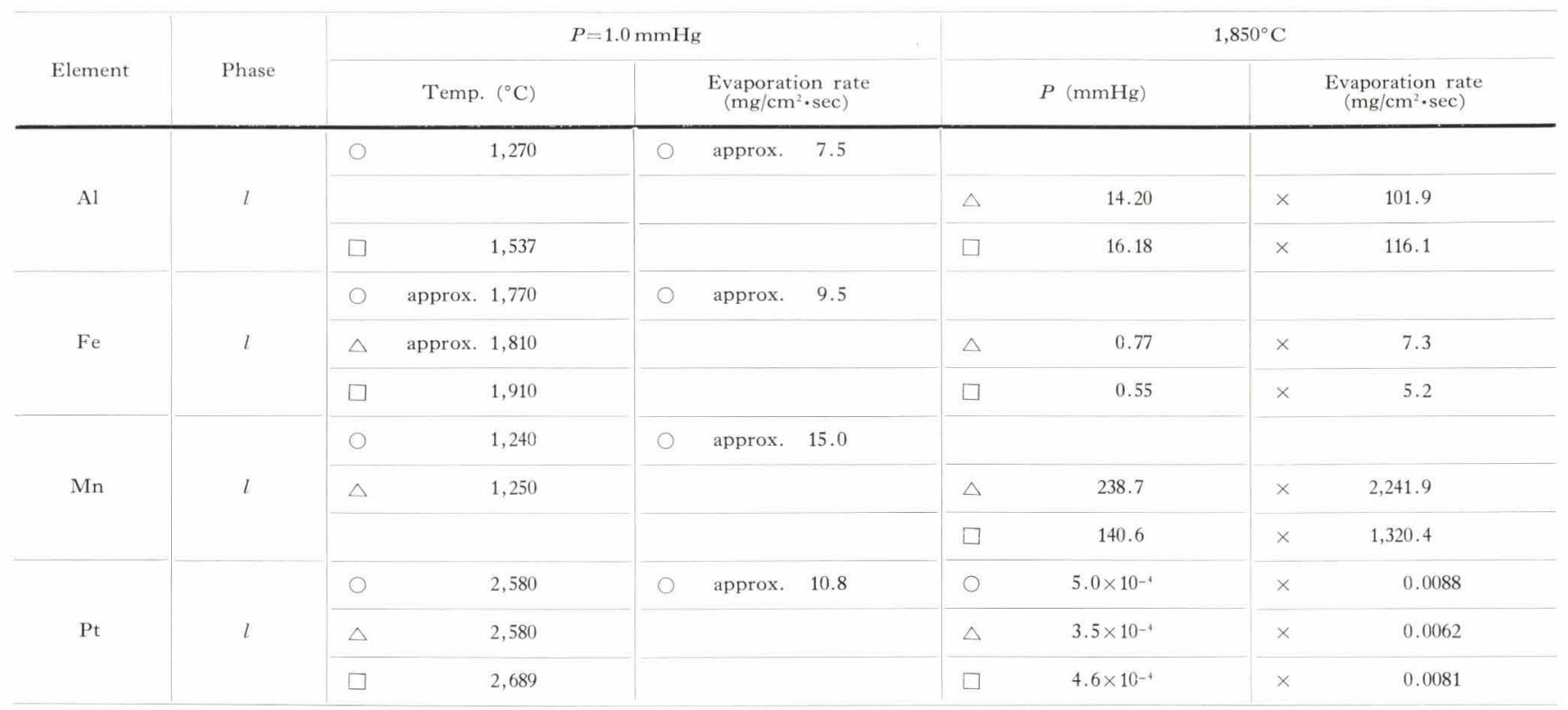

$\triangle$ J.F. Elliot \& M. Gleiser ${ }^{15}$, $\bigcirc$ S. Dushman ${ }^{16)}, \quad \times \quad$ Z. M. Turovtseva \& L. L. Kunin 7 ,

$\square$ Kinzoku Binran (Metals Hand-Book of Japan) ${ }^{17}$ (1960).

ing the values of vapor pressure.

(3) As explained above the formation mechanism of the metallic condensed film has been studied and the eliminating method of carbon monoxide adsorption by this film is considered as follows: reducing of the maximum adsorption areas as much as possible, increasing of the extraction pump speed and, in addition, lowering of the partial pressure of $\mathrm{Mn}$ or $\mathrm{Al}$ in molten sample.

\section{REFERENCES}

1) N. Yoneda: Tetsu-to-Hagané, 43 (1957), 395, 949.

2) N. Yoneda: Hitachi Hyoron, 40 (1958), 8, 1019.

3) S. Sawa: Tetsu-to-Hagané, 38 (1952), 567, 672.

4) "The Determination of Nitrogen in Steel ", J. Iron \& Steel Inst. (U.K.), Spc. Rep. No. 62, B.I.S.R.A. (1958).

5) E. C. Pigott: "Ferrous Analysis", (1953).

6) I. Ogahara, K. Sekimoto \& H. Matsumoto: Tetsu-to-Hagané, 47 (1961), 3, 300.

7) Z. M. Turovtseva \& L. L. Kunin: “Analysis of Gases in Metals", (1959), Publishing House of the Academy of Sciences of the U.S.S.R., (Authorized translation in English 1961).
8) D. L. Gurnsey, R. H. Franklin, A. L. Beach \& G. Guldner: Amer. Soc. Test. Mat., Special Technical Publication No. 222 (1957).

9) "The Determination of Gases in Metals", J. Iron \& Steel Inst. (U.K.), (1960), Spc. Rep. No, 68. Soc. Anal. Chem.

10) S. Maekawa \& Y. Nakagawa: Tetsu-to-Hagané, 46 (1960), $748,972$.

11 D. Smith. L. Estwood, D. Garney \& C. Sims: "Gases in Metals", (1953).

12) K. Sambongi \& M. Ōtani: Tetsu-to-Hagané, 47 (1961), 6, 841-852.

13) A. L. Beach \& W. G. Guldner: Anal. Chem., 31 (1959), 10, 1722.

14) G. Thanheiser \& E. Brauns: Arch. Eisenhüttenze,, 9 (1935 36), 435 .

15) J. F. Elliot \& M. Gleiser: "Thermochemistry for Steelmaking", (1960).

16) S. Dushman: "Scientific Foundation of Vacuum Technique", (1949).

17) Kinzoku Binran (Metals Hand Book of Japan), (1960).

18) M. L. Pearce: Trans. Met. Soc. A.I.M.E. 227 (1963), 1393.

$19)$ C. R. Masson \& M. L. Pearce: Trans. Met. Soc. A.I.M.E. 224 (1962), 1134. 